\title{
Glosas acerca do conceito de progresso em Theodor Adorno e Norbert Elias
}

Dauto João da Silveira'

\section{Resumo}

Este artigo versa sobre o conceito de progresso em Norbert Elias e Theodor Adorno. Este último, diante da ideia de progresso, sempre se mostrou perturbado, pois não conseguia ver nele uma linha inequívoca rumo à libertação de todos os homens: o regresso derivado dos resvales da humanidade sempre o deixou incomodado. Em Elias, o progresso apresenta-se como capacidade de autorregulação, de controle das emoções e pulsões dos homens, bem como o processo de formação da personalidade depende inexoravelmente do desenvolvimento dos processos sociais, portanto dá ao progresso um estado ressaltante.

Palavras-chave: Progresso. Adorno. Elias.

\section{Introdução}

A modernidade é o permanente revolucionar da produção, o abalar ininterrupto de todas as condições sociais, a incerteza e o movimento interno. Todas as relações fixas e congeladas, com seu cortejo de vetustas representações e concepções, são dissolvidas, todas as relações recém-formadas envelhecem antes de poderem ossificar-se 'onde a pobreza se generaliza toda a velha porcaria ressuscita'. (MARX, 20I0b, p. 45).

O debate sobre a teleologia do projeto da modernidade sempre foi objeto de ampla discordância entre os teóricos ocidentais, especialmente no que tange à possibilidade de vivermos em uma sociedade onde o conhecimento técnico e científico seja usado para todos os homens. A crença de que o progresso, advindo das revoluçóes burguesas do século XVIII (cuja ossatura era a ciência e a tecnologia) traria resultados emancipatórios nunca foi razão para se atribuir à modernidade a condiçáo de superioridade diante de toda a história humana. Pelo menos é o que se interpreta da concepçáo adorniana sobre o

I Doutorando em Sociologia pela Universidade Federal do Paraná (UFPR), Curitiba, Paraná, Brasil. Bolsista da Capes - Proc.n9.862/2013-07.E-mail:dautojs@gmail.com. 
progresso, ou seja, a sua hostilidade diante dos "valores positivistas e utilitaristas de uma sociedade de massas moderna dominada pela tecnologia e pelo mercado" (LOWY; VARIKAS, 1992, p. 4).

Náo obstante a força negativa instilada por Adorno ao progresso da modernidade, é mister sublinhar que o seu contrário também é válido, isto é, a modernidade apresenta todos os elementos possíveis para a retirada do homem de um estado menor de existência. Um exemplo dessa possibilidade pode ser atribuído ao papel do esclarecimento, como já aludia Kant, e também ao papel do processo civilizador na história: o conjunto de transformaçóes que permite ao homem produzir uma abrangente teia de interdependência entre si cujo valor é proporcionalmente igual ao seu tamanho.

Portanto, estamos diante de uma dupla condiçăo. Este artigo pretende trazer à luz a concepçáo do progresso em Adorno e em Elias e mostrar que a preocupação de ambos náo se dissocia na essência, contudo tem no segundo um caráter propositivo, ou seja, concebe à modernidade um estado decisivo e sem o qual os homens não alcançariam uma vida melhor. Já em Adorno, o progresso, ainda que inescusável para a retirada do homem do mito, transforma-se em regressão na medida em que o seu desenvolvimento torna-se a sua própria razão de ser: "a maldiçấo do progresso irrefreável é a irrefreável regressáo" (ADORNO, 1985, p. 46).

Partiremos do conceito de progresso advindo da força colossal que emana dos processos revolucionários oitocentistas. Somente através deles as forças produtivas alcançaram um estágio de desenvolvimento jamais imaginado na história e com as quais os homens foram capazes de engendrar uma sociedade capaz de se transformar plenamente. ${ }^{2}$ Somente quando as forças produtivas encontram uma indústria amplamente desenvolvida, o comércio mundial e concorrência entre todos, elas se asseguram na história, permitem o progresso permanente, sem interrupçóes.

O progresso que mira o futuro, ou melhor, que deposita no porvir a condição de libertação dos homens das amarras do passado é o que brota do século XVIII. Falamos isso para esclarecer que, na Antiguidade, a libertaçáo

2 Forças produtivas são aquelas que advêm de tudo que é produzido e combinado pelos meios de produção e pelas forças de trabalho socialmente determinado. 
humana estava amarrada ao passado, o futuro era senáo acreditar na felicidade perdida que os homens tiveram em tempos pretéritos; pura inocência que a ciência encarregou-se de varrer da história, conforme mostraremos em seguida.

Cabe sublinhar, contudo, que o progresso que levou Marx e Engels a depositar à emancipação humana já encontrava nesse mesmo século fortes opositores. Eram os chamados grupos que enxergavam na ordem social existente a expressáo do desastre social latente e que por isso defendiam a conservaçáo da herança existente e do passado que já viveram. Para esse grupo, a expressiva industrialização europeia e a força da ciência e tecnologia que emanava náo garantia a qualidade de vida; proporcionalmente inverso aos que defendiam o progresso enquanto a única possibilidade de fugir do atraso que ainda atormentava o século XVIII.

Curioso que a mesma certeza que os teóricos oitocentistas depositavam no progresso os do século XX viam de modo incerto, ou seja, o que pairava na cabeça dos vintecentistas era: como explicar funestos acontecimentos, como as duas grandes guerras mundiais, o fascismo e o nazismo? Se o progresso do pensamento (ou, na visáo adorniana, Aufklärung) contribuiu para libertar o homem dos temores medievais, dos preconceitos, do pensamento religioso, o mesmo náo se pode atribuir ao progresso técnico e científico. Essas questôes foram colocadas mormente por Adorno, razáo pela qual náo via nesse progresso condiçóes de superar a desgraça humana; e também por Elias, cujos acontecimentos caracterizavam o momento de (des)civilizaçáo.

É bem verdade que o progresso, em Adorno, muitas vezes aparece enquanto uma ideologia a serviço dos interesses dominantes, náo obstante a sua capacidade de levar os homens a superar o seu estado das coisas. Já em Elias ele obedece ao curso do processo de desenvolvimento histórico e permite a transformaçáo da estrutura psicológica e social.

Antes da imersão ao tema, é mister classificar o conceito de progresso em Adorno, uma vez que assim explicitaremos a base do nosso artigo, sem, contudo, prejudicar a intelecção eliasiana sobre o tema. A ideia de progresso, segundo Aguiar (2008, p. 22), tem duas características centrais:

A primeira diz respeito a uma série de acontecimentos que caminham para um sentido desejável, por exemplo, progresso da técnica, progresso do homem; e a segunda diz respeito a uma crença em fatos históricos que se desenvolvem em sentido desejável, no intuito de 
realizar um aperfeiçoamento sempre crescente e geral, ou seja, um progresso da humanidade como todo.

Os teóricos do século XVII em diante (mormente, Descartes, Comte, Hegel, Smith, Marx, Darwin, Adorno e Elias) são tributários da segunda característica, ou seja, os que depositavam fé no desenvolvimento humano permanente. Se em Descartes temos o entendimento de que o futuro é para onde devemos caminhar, uma vez que a história é determinada pela "lei do progresso"; em Smith, temos a felicidade enquanto produto da fé no progresso; em Kant, o esclarecimento como saída da menoridade; em Hegel, o espírito da razão e da esperança do progresso; e, em Marx, a crença nas forças produtivas como motor da história, é no século XX que o conceito de progresso manifesta sensivelmente o seu contrário, ou seja, o engendramento do progresso leva o homem a perder o controle sobre a sociedade.

É durante as duas grandes guerras mundiais que o conceito de progresso em Adorno e Elias se configura e que os dois alemães instilam a possibilidade de o homem experimentar a barbárie. Esse talvez seja o novo contexto do progresso, ou seja, a possibilidade de toda a certeza da teleologia do seu desenvolvimento torna-se o seu contrário.

\section{Progresso em Adorno}

A crítica de Adorno à modernidade adjudica à ideologia do progresso um ponto fundamental para se compreender a relaçáo entre o homem e o seu meio, dito em outras palavras, a possibilidade de vitória do homem diante de tanta falta de liberdade. É bem verdade que há, entre os pesquisadores (pós-adornianos), interpretaçóes divergentes acerca da preocupaçáo da Escola de Frankfurt, mormente a de Adorno, no que concerne ao papel do progresso na modernidade. Para Lowy e Varikas (1992), o alemáo sempre foi a figura antitética da ideologia progressista ocidental, náo construindo um sistema analítico expressivo, contudo salientam que encontramos, ao longo da sua obra, pontos em que essa preocupação aparece mais patente. Um desses pontos é quando Adorno se refere ao comentário hegeliano de que Napoleáo seria o "espírito do mundo montado a cavalo", ou seja, o espírito da razão e da esperança do progresso que Hegel atribuiu à Revoluçáo Francesa foi ironizado por Adorno (1951, p. 45) na seguinte frase: "Eu vi o espírito do mundo, mas náo a cavalo, vi-o nas asas de um míssil". Essa citaçáo talvez traduza bem o 
papel que Adorno relegava à ideologia do progresso, náo obstante enxergasse no desenvolvimento material da história a possibilidade de levar o homem a uma condiçáo de existência superior.

A base da crítica adorniana mira o progresso advindo no Iluminismo, precisamente o que encontrou em Hegel, segundo Lowy e Varikas (1992, p. 10, grifo dos autores), a expressão filosófica mais fina, qual seja:

A reflexão de Adorno lança raízes em toda uma tradição de polêmica, muitas vezes acerba, contra a modernidade burguesa. Ela está ligada a uma corrente profunda que atravessa a história da cultura alemã (e europeia) desde o fim do século XVIII até os nossos dias: o romantismo, não como simples escola literária, mas como uma weltanschauung fundada na crítica da civilização industrial/capitalista moderna a partir de valores sociais e culturais pré-capitalistas. Os dois momentos fortes da evolução dessa corrente são o romantismo 'clássico' do início do século XIX e o assim chamado 'neorromantismo', predominante no fim do mesmo século, particularmente nos meios universitários. Esses dois momentos são fontes essenciais de reflexão adorniana do progresso: fontes que são evidentemente reinterpretadas e reexaminadas por uma filosofia que, apesar de tudo, jamais deixou de reivindicar para si a herança das luzes.

Aguiar (2008), para quem Adorno sempre buscou pela via dialética do progresso a possibilidade de vitória humana, menciona que os vieses entrelaçam-se na cabeça do alemáo: a) o progresso advindo do Esclarecimento (Aufklärung) foi o responsável por libertar os homens do mito; e b) o progresso técnico e científico, apropriado pelos negócios burgueses, por sua vez, foi o responsável por levar o homem novamente ao mito do mercado, ou melhor, introduziu o mito da felicidade por meio do consumo dos bens da indústria cultural. $\mathrm{O}$ primeiro viés é a base sobre a qual o conceito de progresso adorniano se ergue, ou seja, o progresso enquanto um instrumento vigiativo do progresso em si; o responsável pelo afastamento da tragédia.

Fica claro, diante do que foi exposto, que a visão de Adorno está relacionada ao progresso da humanidade na sua totalidade, ou seja, o progresso advindo das técnicas e do esclarecimento só faz sentido se ele estiver a serviço da emancipaçáo humana. Era tudo o que náo acontecia em meados do século $\mathrm{XX}$, especialmente quando a sociedade emergia em confrontos mortais, desperdiçando a possibilidade de liberdade para os homens. A Segunda Guerra Mundial é um acontecimento decisivo na ideia de progresso adorniano, razáo pela qual ele atribuiu toda a capacidade das tecnologias de extermínio ao "espírito do mundo". 
Esse momento histórico é um exemplo de primeira água no constructo adorniano sobre o progresso. Em funçáo disso, no livro Mínima Moralia (ADORNO, 1951) - escrito anos depois da Segunda Guerra Mundial -, o autor faz amargas críticas ao que vimos anteriormente sobre o espírito do mundo hegeliano:

Se a filosofia da história de Hegel tivesse incluído esta época, as bombas-robô de Hitler teriam encontrado o seu lugar ao lado da morte prematura de Alexandre e de outros quadros do mesmo tipo, entre os factos empíricos seleccionados nos quais se expressa de modo imediato e simbólico o estado do Espírito universal. Como o próprio fascismo, os robôs são lançados ao mesmo tempo e sem participação do sujeito. Como aquele, unem a extrema perfeição técnica a uma total cegueira. Como aquele, suscitam um terror mortal e são de todo inúteis.

A lógica da história é tão destruidora como os homens que produz: onde quer que penda a sua força de gravidade, reproduz o equivalente do infortúnio passado. O normal é a morte. (ADORNO, 1951, p. 45).

Entretanto, náo podemos relegar a Adorno apenas a visão dual, ou seja, a visão negativa ou positiva do progresso: subsiste em seus escritos um desenho dialético intrigante. Pelo menos é assim que entendem Lowy e Varikas (1992, p. 207), para os quais "a dialética do progresso implica um ponto de vista que critica a ideia de progresso sem removê-lo do horizonte conceitual”. Essa dialética atravessa a ideia de progresso adorniana. O que vemos é a latente preocupaçáo entre o progresso da humanidade (emancipaçáo humana) e o progresso do conhecimento (possibilidade real de débâcle mundial), onde os avanços tecnológicos e científicos, ou ainda os progressos das destrezas e do conhecimento - nas palavras do frankfurtiano -, náo eram usados para satisfazer o potencial de liberdade plena dos homens. Aliás, Adorno chega a aludir que o conceito de progresso é táo ingrato que o seu emprego na maioria das vezes incorre em equívocos grosseiros: "somente sáo verdadeiras aquelas reflexóes sobre o progresso que mergulham nele sem deixar de manter distância, que evitam os fatos e significados pontuais paralisadores" (ADORNO, 1962, p. 218).

Portanto, atribui a possibilidade de se evitar a catástrofe à forma mais acabada de progresso, ou seja, o progresso enquanto um conditio da história a serviço da revoluçáo - na medida em que ela lance o fim do sofrimento humano, o fim do progresso, das destrezas e do conhecimento nomeadamente burgueses.

É nesse ponto que Adorno adverte que a compreensáo do progresso sempre esteve atrelada ao conceito de sociedade: 
Sem a sociedade sua ideia seria inteiramente vazia; todos os seus elementos derivam dela; se a sociedade não tivesse passado da horda caçadora e coletora para a agricultura, da escravidão para a liberdade formal dos sujeitos, do medo dos demônios à razão da carência ao afastamento das pragas e da fome e à melhora das condições de vida em geral: se pois procurássemos manter pura a ideia de progresso more philosofico, talvez debulhando-a da essência do tempo, então ela não teria conteúdo algum. (ADORNO, 1992, p. 223).

Por mais contraditório que pareça, a ideia de progresso, ainda que venha da sociedade, náo se dissolve nela; opóe-se a ela. Trata-se de um desenho dialético em que negar a sociedade autoriza o encontro de si e para si. É como compreender algo fora do seu próprio corpo; algo que se realiza efetivamente desvencilhando-se do seu próprio criador, de quem o articula. $\mathrm{Ou}$, como alude Adorno (1992, p. 223), "derivado da sociedade, ele reclama a confrontaçáo crítica com a sociedade real. Indelével nele é o momento da redenção, por secularizado que esteja”.

Concordamos com Lowy e Varikas (1992, p. 206), para os quais "a reflexáo de Adorno sobre o progresso é cortada por uma tensáo permanente", quando afirmam que essa dupla condição do progresso, entre a produção de conhecimento e destreza e o permanente progresso da humanidade, "revela o duplo caráter de uma dinâmica que sempre desenvolveu o potencial de liberdade ao mesmo tempo que a realidade de opressáo" (p. 208).

Parece patente, na defesa adorniana, que o potencial humano, ou seja, a capacidade despreocupada dos homens em se manifestar, seja na instância cultural, filosófica ou artística, desfaz-se na modernidade, sofre uma degradaçáo em relaçáo à vida pré-moderna. Com base nessa afirmaçáo, podemos afirmar que, "com o progresso, o que os homens perderam foi o componente humano de cultura" (ADORNO, 1992, p. 229). É nesse momento que a critica à Indústria Cultural ganha sentido abrangente: ela assume na sociedade capitalista o exercício do controle social e torna-se uma poderosa fonte lucrativa de grandes monopólios, alude Dalbosco (2008). Ainda que encontremos críticas honestas, no seio das quais aparece a fragilidade da indústria cultural adorniana, o que parece válido é que, em última análise, o componente humano da cultura continua sendo transformado em mercadoria nos dias atuais.

Diante disso, é mister destacar que Adorno náo se apropria da miragem clássica marxiana para a qual o progresso das forças produtivas levaria a humanidade a superar o modo de produção capitalista. Marx é decisivo ao mencionar 
que as forças produtivas têm o papel de levar os homens a superar o seu estado menor de existência e que, no modo de produçáo capitalista, essa capacidade torna-se um elemento revolucionário ainda mais compreensivo. Afinal, o que dizem os escritos marxianos sobre o progresso? Ou melhor, há uma possível teoria do progresso na obra de Marx? É possível afirmar que o progresso torna-se um conditio sine qua non na obra de Marx?

Para esses questionamentos, a resposta mais segura advém da sua própria apreensão da história. Ou seja, a história enquanto uma conexidade de geraçôes no cerne das quais se manifesta, inequivocamente, todo o potencial de riqueza social deixado pela geraçáo pretérita. É dessa forma que surge "a história da humanidade, que é tanto mais história da humanidade quanto se desenvolveram as forças produtivas dos homens e, consequentemente, as suas relaçôes sociais" (MARX, 2010a, p. 76).

Náo raro, em Marx (2010a, p. 43) o progresso material advindo da burguesia recebe contornos expressivos:

A burguesia não pode existir sem revolucionar incessantemente os instrumentos de produção, por conseguinte, as relações de produção e, com isso, todas as relações sociais. A conservação inalterada do antigo modo de produção era, pelo contrário, a primeira condição de existência de todas as classes industriais anteriores. Essa subversão contínua da produção, esse abalo constante de todo o sistema social, essa agitação permanente e essa falta de segurança distinguem a época burguesa de todas as precedentes.

Portanto, o progresso aparece enquanto um instrumento que levaria a humanidade a um caminho cujo telos é a emancipaçáo de todos os homens. É assim que podemos entender a seguinte afirmaçáo: "com o rápido aperfeiçoamento dos instrumentos de produção e o constante progresso dos meios de comunicaçáo, a burguesia arrasta para a torrente da civilizaçáo todas as naçóes, até as mais bárbaras" (MARX, 2010a, p. 79). Ou ainda:

A burguesia, em seu domínio de classe de apenas um século, criou forças produtivas mais numerosas e mais colossais do que todas as gerações passadas em seu conjunto. A subjugação das forças da natureza, as máquinas, a aplicação da química na indústria e na agricultura, a navegação a vapor, as estradas de ferro, o telégrafo elétrico, a exploração de continentes inteiros, a canalização dos rios, populações inteiras brotando da terra como por encanto - que século anterior teria suspeitado que semelhantes forças produtivas estivessem adormecidas no seio do trabalho social. (MARX, 2010a, p. 8I). 
Nessa mesma direçáo, Engels (1979) nos traz um grande exemplo sobre a Ilustraçáo do século XVIII, cujo advento apresentava uma maquiagem de liberdade total, mas depois revelou a sua verdadeira face burguesa, onde tudo era expressão do seu espírito. Era o período do reinado da razão suprema, em que "a religiáo, a observaçáo da natureza, a propriedade, a ordem pública; tudo era submetido à mais desapiedada crítica; tudo o que existia devia justificar sua existência perante o tribunal da razáo ou renunciar a continuar existindo" (ENGELS, 1979, p. 17).

O que nos parece curioso é o fato de que Adorno náo percebeu, pelo menos nos textos referentes ao progresso, que o caminho da emancipaçáo humana transcorre o mesmo curso da regressáo (alienaçáo) na modernidade. A sociedade moderna burguesa é a expressão superior da humanidade. Ela é responsável pela conexão de todos os homens, somente nela o intercâmbio, da forma que está posto, permite a universalização da vida. Diz Marx (2010b, p. 165): "o retorno completo do homem para si mesmo como ser social (isto é, humano) - retorno consciente e realizado no interior de toda riqueza do desenvolvimento anterior" - só pode ser concebido no vir a ser, na superação do próprio capitalismo. A sociedade do vir a ser é "a soluçẫo verdadeira do conflito entre o homem e a natureza e entre o homem e o homem - a verdadeira solução da luta entre existência e essência, entre objetivação e autoconfirmação, entre liberdade e necessidade entre o indivíduo e o gênero" (MARX, 2010b, p. 165).

A grande perturbaçáo de Adorno, pelo menos até o livro Dialética negativa, de 1966, é explicar como o progresso está revestido do seu oposto, ou seja, ao falar em progresso náo podemos nos esquecer do seu regresso. No progresso há algo que fica fora do conceito; não podemos, ao definir o progresso, conservar o ruim, segundo Adorno.

É na Dialética negativa que o autor vai construir todo um esquema analítico para formular uma crítica à noçáo tradicional sobre o conceito, ou seja, o seu objetivo era destacar o que foge da identidade com o conceito, conforme alude Domingues (2013). "Ir além do conceito por meio do conceito" (ADORNO, 2009, p. 22), somente assim ele conseguiria compreender o progresso na modernidade.

O que não vemos em Adorno é a intelecção de que, independente de o progresso carregar consigo o seu oposto, o que ele nos oferece é a negação dos 
limites do passado. Ainda que o porvir seja uma construçáo social, tensionada pelos antagonismos de classes, a garantia que temos é a de que o progresso da humanidade cria as condiçóes peremptórias de uma vida de outro tipo.

\section{Elias e o progresso}

Se a visão de progresso em Adorno é sempre algo conflituoso, não podemos dizer o mesmo de Norbert Elias, para quem o desenvolvimento da humanidade pode ser entendido como um amplo processo de civilizaçáo humana em que o conceito de progresso é central. Portanto, todo o processo civilizacional que perpassa a obra eliasiana é senáo a tentativa de apresentar a possibilidade de uma vida autorregulada, com controle permanente das pulsóes e das emoções, bem como incapaz de regressar aos estágios primitivos. É dessa forma que entendemos, com base em Elias, que o progresso é a expressáo de uma sociedade que evoca a autorregulaçáo crescente dos indivíduos. Ou, nas palavras de Haro (2010, p. 1),

la civilización, como proceso, supone que la conducta y las emociones individuales sean progresivamente autocontroladas en paralelo a la constitución de monopolios centrales de la violencia y el incremento de la diferenciación social, la especialización funcional y la interdependencia.

Cabe, contudo, esclarecer que Elias não foi um teórico do progresso, ainda que tenha se dedicado ao tema em sua larga obra. Dois exemplos dessa dedicação são: a) o livro Escritos e ensaios, em que o tema aparece no último capítulo com o título "Para uma fundamentaçáo de uma teoria dos processos sociais". Escrito em 1979, esse capítulo traz uma síntese sobre a evoluçáo dos processos sociais e sobre a importância do progresso para a autocompreensão da Europa sobre o mundo; e b) o livro Processo civilizador (vol. I): uma história dos costumes, em que o tema aparece no capítulo primeiro, "Da sociogênese dos conceitos de civilizaçáo e cultura", com o registro da antítese entre cultura e civilizaçáo para os europeus, e no Apêndice (Introduçáo à ediçấo de 1968), quando apresenta um "estado da arte" do progresso e desenvolvimento social no Ocidente.

Entretanto, isso náo impede que façamos, na exiguidade deste artigo, uma aproximaçáo responsável entre o progresso e o que ele chamou de processo civilizacional, pressupondo que civilizaçáo descreve "um processo ou, pelo menos, seu resultado. Diz respeito a algo que está em movimento constante, movendo-se incessantemente para a frente" (ELIAS, 1993, p. 159). 
O pensamento de Elias sobre o progresso é tributário do pensamento do século XVIII, especialmente o que se mostrava preocupado com os rumos da humanidade, ou ainda das teorias dos processos sociais de longo prazo, como observamos na obra de Augusto Comte. Concordamos com Silva (2010, p. 14) quando menciona que, em Auguste Comte, "a questáo pertinente que se colocava era como manter a evoluçáo da sociedade no caminho regular e moralmente correto, ou seja, Comte pensava a sociedade de uma forma geral, desenvolvendo um processo". A preocupaçáo comteana sobre o processo de desenvolvimento da humanidade banha o horizonte intelectual de Elias e permite que questóes acerca do futuro da humanidade, da capacidade humana de resolver os problemas de toda ordem e das configuraçóes emocionais e controle dos atos e pulsóes tornem-se questóes prementes do seu pensamento.

Outro autor clássico da sociologia a quem Elias náo poupa elogios pela contribuição acerca do constructo teórico engendrado é Marx, ainda que dissinta profundamente. $\mathrm{O}$ "apreço" por Marx vem pela correçáo que este fez da obra de Hegel trocando a força motriz de todas as transformaçóes da sociedade do "espírito" pela produçáo de bens para a satisfaçáo das necessidades prementes do homem. Com isso, segundo Elias (2006, p. 200), Marx colocou no "centro do seu programa de pesquisa o problema da transformaçáo da sociedade humana ou, em outras palavras, a ordem imanente da sequência de etapas sociais”. Aqui já vemos o útero da concepçáo eliasiana, qual seja: o de conceber a sociedade enquanto uma permanente máquina de transformaçáo cuja miragem é a formaçáo de homens capazes de se autorregularem diante das contradiçóes da sociedade. Dito de outro modo, a história é o caminhar (não planejado) de geraçóes, em que as últimas herdam todo o processo de conhecimento engendrado pela pretérita e aprofundam a integraçáo e o relacionamento entre os homens (em que o distanciamento das pulsóes, emoçóes e paixóes torna-se o seu imperativo), produzindo um caminho cada vez mais adequado à sobrevivência humana.

Elias (1993) é categórico ao mencionar que o elemento que subjaz o processo civilizador é o espraiamento das redes de relacionamento, o aumento do grau de interdependência entre os indivíduos, resultado da progressiva divisáo das funçôes sociais na história. 
Quanto mais diferenciadas elas se tornavam, mais crescia o número de funções e, assim, de pessoas das quais o indivíduo constantemente dependia em todas as suas ações, desde as simples e comuns até as complexas e raras. À medida que mais pessoas sintonizavam suas condutas com a de outras, a teia de ações teria que se organizar de forma sempre mais rigorosa e precisa, a fim de que cada ação individual desempenhasse uma função social. (ELIAS, 1993, p. 195-196).

Portanto, a configuraçáo social descrita (mais abrangente e complexa) explicita um estado de coisas que é inversamente proporcional ao período da Antiguidade; dado que a Antiguidade, para Elias (2006, p. 199), é considerada o período em que a noção de futuro, de felicidade plena dos homens, estava voltada, invariavelmente, para o passado: "durante milênios os seres humanos viram o desenvolvimento da humanidade como uma decadência". É sobre essa diferenciação que se erguerá o conceito de progresso eliasiano, ou seja, é na modernidade que a reviravolta procede, essencialmente atrelada às mudanças de estrutura social e da personalidade humana, tal como aparece no arranjo geral que apresentamos na introduçáo deste artigo.

Não há como dissociar a ideia de progresso à de civilização, uma vez que a segunda tornou-se o exemplo de superioridade ocidental, ou, nas palavras de Norbert Elias (2011, p. 23), "a consciência que o ocidente tem de si mesmo" e, mais ainda, "o orgulho pela importância de suas naçóes (especialmente Inglaterra e França) para o progresso do Ocidente e da humanidade".

É assim que o século XIX constrói a ideia de que o progresso resultaria em uma vida melhor e em liberdade para o Ocidente. A imagem de que o futuro melhor estava voltado para o passado é sepultada no cemitério das narrativas mortas. O século XIX, da mesma forma que foi para Adorno, foi para Elias o século do progresso, o século da possibilidade de uma vida digna e livre com base nos avanços da ciência e tecnologia, mas não só; também no avanço da capacidade humana de dissolver as conquistas do Ocidente e transformá-las em produto universal.

Náo obstante a crença no progresso, o século XIX também assistiu ao crescimento das vozes que o rejeitavam, haja vista a deterioraçáo do estado presente. Elias (2011, p. 219) esclarece que "não só as elites pré-industriais dos Estados dinásticos, mas também grupos mais amplos de trabalhadores - acima de tudo os que se ocupavam na agricultura e ofícios artesanais cujo meio de vida tradicional estava sendo corroído" - aumentavam o coro dos descrentes. 
Foi somente com o advento de transformaçóes sociais profundas, com o controle sistemático da natureza externa, com a crença nas virtudes da razão, com o fluxo incessante de inovaçóes e com o modo acabado com que se manejavam as relaçóes com o todo que se permitiu que o coro das vozes contrárias ao progresso também ganhasse expressão na modernidade. A sua força é proporcionalmente igual ao grau de desenvolvimento que assumiam as sociedades industrializadas. Ou ainda, quão mais alta era a sinfonia do progresso, mais alto era o grito dos pessimistas, a ponto de, no século XX, o conceito de progresso tornar-se lábil.

Nesse momento, Elias explicita um exemplo de primeira água que evanesce a ideia de progresso voltada para o avanço da ciência e tecnologia do século XIX, ou seja, o autor apresenta o seguinte questionamento: se essa ideia novecentista tem raízes profundas, como explicar a crise do progresso no século XX se é justamente nele que obras olímpicas de ciência e tecnologias são realizadas? Se o século XIX é o da certeza da ideia do progresso enquanto a redenção da humanidade, o século XX é o seu enterro.

As guerras mundiais vintecentistas não foram apenas para Adorno (2011) o trauma incurável que sofreu a modernidade. Para Elias, as guerras mundiais foram a certeza do regresso da humanidade, aqueles momentos em que a sociedade sofre a (des)civilização.

As guerras repetidas, o perigo incessante de guerra, e a ameaça de armas nucleares e científicas certamente contribuem para essa coincidência de progresso em aceleração, particularmente nos campos científico e técnico, com confiança decrescente no seu valor e no progresso em geral. (ADORNO, 201 l, p. 220).

Seja como for, o progresso apresenta-se paradoxal para Elias (2006): ainda que a modernidade eleve a capacidade humana de interdependência, de autorregulação e de controle das pulsóes e emoçóes, é notória a sua profunda preocupação de dúvida sobre o valor do progresso.

[...] há hoje um movimento no sentido da diminuição da desigualdade entre outsiders e estabelecidos, sejam eles trabalhadores e empresários, colonizados e potências coloniais, mulheres e homens. Do ponto de vista humano, isso é um progresso, Mas, ao mesmo tempo, esse movimento contribui para o incremento de tensões sociais e pessoais e de conflitos, que aumentam o sofrimento dos seres humanos e levantam dúvidas sobre o valor de seus esforços por progresso. (ELIAS, 2006, p. 202). 
O debate sobre a possível (des)civilização da humanidade não chegou a ser trabalhado por Elias, ainda que as duas guerras mundiais, o Holocausto nazista, a envergadura da repressáo maoísta ou a limpeza étnica na antiga Iugoslávia tenham sido observadas enquanto momentos cruciais do processo de labilidade da civilização mundial.

Concordamos com Haro (2010, p. 5) quando defende que as fases de (des)civilização não são suficientemente fortes para desfigurar o processo crescente e dominante de civilização, ou seja, "pudieron existir fases, momentos, periodos más o menos amplios de carácter des-civilizado que finalmente cederían ante el empuje de las tendencias civilizatórias".

Contudo, parece-nos oportuno destacar que essa compreensão permite creditar a potencialidade da ideia do progresso: se para Adorno o desastre do século XX estava associado à incapacidade de o avanço técnico e científico voltar-se à libertaçáo humana, isso náo acontece na visáo de Elias (2011, p. 222), para quem "as oportunidades de um futuro melhor são ainda muito grandes para as primeiras naçóes que se industrializaram”.

Mesmo desse modo, fica inapropriado instilar à obra de Elias um caráter teleológico, como tentaram alguns teóricos do final do século XX, ainda que muitas vezes as evidências insistam em confirmar. Parece-nos mais razoável inocular o caráter do progresso advindo dos processos de longa duração, pressupondo que eles, no curso da história, tendem a levar a humanidade para um estado melhor de coisas. É bem verdade que a história promove os seus momentos de (des)civilizaçáo, contudo náo acreditamos que ela se responsabilize pela ruína ou pelo desmembramento do corpus solidum do progresso engendrado:

o que Elias observou e procurou transmitir é que as complexas mudanças sociais, sempre em curso, formam processos cujas direções específicas, embora não teleologicamente determinadas, seguem um fluxo e apresentam regularidades passiveis de observação (SILVA, 2010, p. 101).

Ainda que consideremos relevante o debate acerca da teleologia, não é oportuno aprofundar a discussão. É mister considerar, sobre o que foi dito, que Elias (1993, p. 200) apresenta a civilizaçáo como responsável pela regulaçáo do indivíduo em sociedade: "na verdade, foi todo o molde social, o código de conduta, que mudaram e, de acordo com as mudanças, náo apenas esta ou aquela forma específica de conduta, mas todo o padrão, toda a estrutura da 
maneira como indivíduos pautam sua vida”. Destarte, toda essa estrutura, que historicamente molda o indivíduo, permite uma maior teia de interdependência no seio dos espaços sociais ampliados.

Dessa forma, destacamos a premissa segundo a qual, em sociedades avançadas complexas, o nível de exigência intelectual fina, bem como as condiçóes psicológicas do indivíduo e a sua capacidade de consciência de si mesmo tornam-se algo inescusável, sem o qual o indivíduo náo garante a sua (inter-) relação dilatada. Ao contrário do que corriqueiramente se observa, em cabeças ingênuas, acerca das consequências negativas do desenvolvimento consciente das tecnologias, máquinas e técnicas de todo tipo para o indivíduo e para seus processos integradores, sublinhamos que é partir dele que a possibilidade de superaçáo dos limites impostos pelas sociedades arcaicas se confere.

Nesta proposta de artigo, acreditamos que o progresso eliasiano apresenta elementos que permitem defender a tese de que a possibilidade de libertaçáo do homem dos limites impostos pela natureza e a formaçáo de uma rede total de interdependência só sáo possíveis em sociedades complexas, altamente desenvolvidas pela força da ciência. Sem esquecer contudo, que a violência não desaparece (pelo menos completamente), deixa de ser externa para se tornar interna, uma forma de autocontrole.

\section{Considerações finais}

O conceito de progresso é, senão, a força que brota das relaçóes que os homens mantêm ao longo da história, em que a cada passo da sociedade - em sua busca da supressáo das limitaçóes do passado - é engendrada uma unidade universal inalienável entre eles, cujo espírito imanente é a realização de um porvir supremo.

É lícito afirmar que esse conceito carrega implicitamente a noção dialética, uma vez que, no seu interior, pulsam as contradiçóes sociais sem as quais o próprio progresso não existiria. Pensamos que é dessa forma que Marx acreditava na teleologia da história, especialmente quando divergia de Hegel acerca do espírito universal que acompanha os homens. $\mathrm{O}$ materialismo histórico dialético é o registro desse acerto de Marx, ou seja, a tese de que cada geração se apropria das forças produtivas deixadas pela geraçáo passada e as transforma de acordo com as necessidades históricas postas parece-nos categórica. 
Esse progresso é mais de Adorno do que de Elias, ainda que no primeiro a possibilidade de regressáo receba um revestimento crítico que reconfigura o conceito apresentado. Já em Elias, o que ele chamou de (des)civilizaçáo náo foi táo determinante assim para a sua obra, ainda que os fortes abalos do século XX tenham o impressionado. Foi assim que Elias (2006, p. 63) mencionou que "o impulso civilizador em direçáo a uma humanidade mais unida vem seguido de um contraimpulso (des)civilizador".

Talvez devêssemos concluir este artigo tecendo breves reflexóes sobre o progresso no século XX, a despeito da intelecçáo que ambos tiveram das guerras mundiais e do equívoco - a nosso juízo - em temer os períodos de latejo por que passa a sociedade.

De acordo com o que dissemos sobre a regressáo em Adorno, cabe um questionamento: por que ele instila às guerras mundiais um momento de débâcle da humanidade? Não resta dúvida de que as guerras e as consequências advindas delas sáo fatos desastrosos que póem em risco a configuraçáo de um determinado período histórico. Mesmo assim, devemos observá-las a partir da corrida por conquistas, ou pela apropriaçáo do excedente da riqueza mundial a que os países se submetem entre si.

Estamos de acordo que a destruição feita pelos povos bárbaros às forças produtivas do Império Romano registra um período de regressáo. Contudo, se olharmos para tal período, veremos que os bárbaros (um povo cuja relaçáo com a sociedade era diametralmente distinta da dos romanos) apenas derrubaram o último "Cavalo de Batalha" romano, ou seja, a decadência econômica e a sistemática opressáo do Império, com sua burocracia e agressivos impostos agrícola, como lembra Woods (2002), teve mais peso do que a irrupção bárbara.

Afora isso, as guerras sempre foram o momento de inflexáo do progresso, em que a razão suprema sempre foi superar a possibilidade de recaída a um período nefasto, por isso parece-nos desproporcional compreender o regresso da forma como aborda Adorno. Obviamente que há oposiçáo no progresso e que o seu curso não garante à humanidade um final inequívoco. Contudo, o que ele nos permite é a formaçáo de uma sociedade mais distante das amarras e da subjugação humana à natureza e ao meio. As decisóes sobre a capacidade de convívio entre os homens seguem sendo determinadas pelas contradiçóes sociais.

Ao mesmo tempo, concordamos com o adágio de que o nazismo foi inquestionavelmente um momento histórico que tentou dar a um povo poderes, 
liquidando com as pessoas consideradas culturalmente menores. $\mathrm{Ou}$, como afirma Fausto (1998, p. 143),

A crença de que a grandeza presente e futura da Alemanha e de toda a 'raça ariana' dependia da luta pela 'pureza racial'; essa 'pureza', concebida em termos biológicos, impunha o afastamento e, no limite, a destruição dos grupos humanos 'inferiores', cujo epítome era representado pela 'raça' judaica.

Nesse mesmo prisma, Elias dá outra interpretaçáo ao nazismo, isto é, evoca a qualidade do habitus nacional alemáo enquanto uma consequência da história de formaçáo do povo germânico para explicar o nazismo. A história alemá para Elias é profundamente conflituosa, descontínua e vivida sob a égide das rivalidades dinásticas. Essas características sobrepuseram e formaram a identidade nacional ou o habitus nacional ariano do início do século XX. Portanto, o nazismo foi produto de um longo processo histórico de formaçáo da personalidade da raça ariana e do Estado alemáo. É assim que entende Fausto (1998, p. 147) quando afirma que:

Com tais características, o habitus, transmitido de geração em geração, produziu no povo alemão um desejo ardente de unidade, que emergiu recorrentemente na Alemanha em situações de crise. A autoimagem de que os alemães não eram capazes de conviver sem discórdias e disputas encontrou expressão no sonho de encontrar um soberano ou um líder poderoso, capaz de produzir a unidade e o consenso.

A análise eliasiana tira o peso das costas do indivíduo enquanto responsável por ordenar isoladamente toda a regressáo social. Coloca a regressão de um tempo nas costas dos processos sociais contraditórios de longa duração que os homens em permanente interdependência engendram. Essa forma de analisar parece-nos evidenciar que o regresso sempre se apresenta prenhe de contradiçóes sociais, ou seja, há progresso nesses períodos de decadência, uma vez que ela manifesta os passos concretos dos homens ao longo do tempo, a evoluçáo das capacidades de autorregulaçáo e o aprimoramento do controle das pulsóes e emoçóes, só para citar três facetas. Só assim podemos aceitar a seguinte afirmação de Norbert Elias (1993, p. 235):

A totalidade da sociedade europeia, o substrato do que é, até agora, o último e mais forte surto civilizador, de modo algum pode ser considerada a unidade pacífica que, às vezes, parece ser em edifícios harmonísticos de pensamento. Ela não começou sendo um todo harmonioso, no qual se introduziram conflitos, com que pela má vontade e incompreensão 
de determinadas pessoas. Em vez disso, tensões e lutas - tanto quanto as dependências mútuas de pessoas - constituíram parte integral da sua estrutura, afetando decisivamente a direção em que ela mudou.

É dessa forma que o regresso náo pode ser analisado isoladamente como um momento peremptório de desmanche absoluto da sociedade. O caminho do progresso permanente também convive com essas questóes.

\section{Referências}

ADORNO, T. Dialético do esclarecimento: fragmentos filosóficos. Rio de Janeiro: J. Zahar, 1985. . Dialética negativa. Rio de Janeiro: J. Zahar, 2009.

. Introduçáo à sociologia da música. Sáo Paulo: Unesp, 2011.

. Minima moralia. Lisboa: Ediçóes 70, 1951.

Progresso. Lua Nova [on-line], n. 27, p. 217-236, 1992.

AGUIAR, W. F. Filosofia, música e sociedade: a noção de progresso em Theodor Adorno. Uberlândia. Dissertação (Mestrado em Filosofia). Universidade Federal de Uberlândia, 2008.

DAlBOSCO, C. A. Problemas de atualidade da teoria crítica? In: DURÁO, F. A. et al. (Org.). A indústria cultural hoje. São Paulo: Boitempo, 2008.

DOMINGUES, L. de L. da S. A dialética do progresso em Theodor Adorno W. Adorno: um estudo introdutório. Revista Urutágua - acadêmica multidisciplinar - DCS/UEM, n. 29, p. 110-122, maio/out. 2013.

ELIAS, N. Escritos e ensaios. Rio de Janeiro: J. Zahar, 2006.

O processo civilizador, vol. I: uma história dos costumes. Rio de Janeiro: J. Zahar, 2011.

O processo civilizador, vol. II: formaçáo do estado e civilizaçáo. Rio de Janeiro: J. Zahar, 1993.

ENGELS, F. Anti-Dühring. Rio de Janeiro: Paz e Terra, 1979.

FAUSTO, B. Uma interpretaçáo do nazismo, na visão de Norbert Elias. Mana, Sáo Paulo, v. 4, n. 1, p. 141-152, 1998.

HARO, F. A. de. La posibilidad de des-civilización. Sociologia, Problemas e Práticas, Oeiras, n. 63, p. 91-112, maio 2010 . 
LOWY, M.; VARIKAS, E. A crítica do progresso em Adorno. Lua Nova, Sáo Paulo, n. 27, p. 201$216,1992$.

MARX, K. Manuscritos econômicos filosóficos. Sáo Paulo: Boitempo, 2004.

O Manifesto Comunista. São Paulo: Boitempo, 2010a.

_ Cultura, arte e literatura: textos escolhidos. São Paulo: Expressão Popular, 2010 b.

SILVA, R. L. Processo e figuraçáo: um estudo sobre a Sociologia de Norbert Elias. Campinas. Tese (Doutorado em Sociologia). Universidade Estadual de Campinas, 2010.

WOODS, A. Civilização, barbárie e a visão marxista da história. Revista Esquerda Marxista, Sáo Paulo, 2002.

\section{Notes on the concept of progress by Theodor Adorno and Norbert Elias}

\section{Abstract}

This paper discusses the concept of progress in Norbert Elias and Theodor Adorno. The latter, on the idea of progress, has always been upset because I could not see him clear a line toward the liberation of all men: the return derived from resvales humanity always made him uncomfortable. In Elias, progress is presented as the capacity for self-regulation, control of emotions and impulses of men, as well as the process of personality formation depends inexorably development of social processes, therefore, gives a state remarking progress.

Keywords: Progress. Adorno. Elias. 